\title{
Dois Pesos e Duas Medidas: a projeção da colonialidade nas políticas de migração e de cidadania da União Europeia
}

Recebido: 21-10-2018

Aprovado: 10-01-2019

Karine de Souza Silva ${ }^{1}$ Ivan Vieira Piseta ${ }^{2}$

\section{Introdução}

O modelo integracionista europeu reproduz algumas das mesmas contradições e limitações que corroem as bases do Estado e que se mantém como legados da Modernidade. As políticas migratórias e culturais da União Europeia (UE) mimetizam determinados mecanismos de exclusão e de hierarquização que atestam para a perpetuação dos processos de colonialidade que, por sua vez, seguem vigentes por meio de estruturas de poder que se sustentam em normas e instituições.

A reprodução do esquema de hierarquização racial dos indivíduos no plano supranacional, inerente ao Estado, demonstra a ambivalência dos direitos de cidadania e migratórios e a seletividade na sua aplicação, já que apenas atingem de maneira plena os migrantes que gozam do estatuto de cidadania europeia.

A construção social da raça como base do sistema-mundo colonial moderno serviu de justificativa à dominação, uma vez que classificou os seres humanos em superiores e inferiores, respectivamente europeus e não-europeus, e ofereceu as chaves para a efetivação

\footnotetext{
${ }^{1}$ Prof $^{\mathrm{a}} \operatorname{Dr}^{\mathrm{a}}$ Karine de Souza Silva. Professora dos Programas de Pós-Graduação em Relações Internacionais e em Direito da Universidade Federal de Santa Catarina (UFSC). Pesquisadora Produtividade em Pesquisa PQ $\mathrm{CNPq}$. Titular da Cátedra Jean Monnet da União Europeia e da Cátedra Sérgio Vieira de Mello CSVM/ACNUR. Coordenadora do "EIRENE - Centro de Pesquisas e práticas Decoloniais e Pós-coloniais aplicadas às Relações Internacionais e ao Direito Internacional" e do Projeto de Extensão CSVM para Migrações e Refúgios. Esta investigação foi financiada pelo CNPq. Brasil. E-mail: karine.silva@ufsc.br

${ }^{2}$ Ivan Vieira Piseta. Graduado em Relações Internacionais na Universidade Federal de Santa Catarina (UFSC). Foi extensionista da Cátedra Sérgio Vieira de Mello para Migrações e Refúgios ACNUR/UFSC. Pesquisador do "EIRENÈ - Centro de Pesquisas e práticas Decoloniais e Pós-coloniais aplicadas às Relações Internacionais e ao Direito Internacional”. Brasil.
} 
do empreendimento colonial. O fim das administrações coloniais não dissipou as hegemonias do passado, uma vez que ainda operam as locomotivas que depreciam a diferença e preservam as hierarquias por meio da colonialidade do poder (QUIJANO, 2005; GROSFOGUEL, 2009), do saber (LANDER, 2000) e do ser (MALDONADO-TORRES, 2007).

O objetivo deste artigo é evidenciar que as políticas de migrações e de cidadania da União Europeia reproduzem a colonialidade em escala supranacional porque perpetuam as hierarquizações coloniais entre europeus e não-europeus fundadas na ideia de raça.

A política de cidadania refere-se ao conjunto de ações do bloco destinadas a preservar o patrimônio cultural de seus Estados-Membros, bem como ressaltar valores comuns que atestem para construção de uma identidade única europeia. A atribuição da cidadania supranacional é um esforço que consiste formar um sistema de concessão de direitos ao "cidadão europeu" de modo semelhante ao que ocorreu durante o período de formatação Estado-Nação moderno no século XVII, que procurou emancipar (o cidadão) para legitimar a regulação (do Estado). Já as políticas de migrações referem-se aos esforços das Instituições da União, nomeadamente o Conselho da União Europeia, a Comissão Europeia e o Parlamento Europeu (doravante "Conselho", "Comissão" e "Parlamento") em adquirir cada vez mais competências na tentativa de "supranacionalizar" sobre os aspectos de controle de fronteiras, migrações regulares e irregulares, integração de imigrantes, refúgio e a atuação em política externa.

Parte-se aqui do pressuposto que o discurso que propaga a promoção da igualdade na diversidade e do respeito aos direitos humanos possui alcance e intencionalidades limitados uma vez que é aplicado plenamente a apenas aos cidadãos europeus, ao passo que coloca em constante suspeita a humanidade de outros, cujas identidades são racializadas.

Utilizando-se das abordagens epistemológicas decoloniais e pós-coloniais, este trabalho desconstrói a tese de que a integração regional europeia supera os elementos de classificação social presentes no Estado nacional europeu e levanta a hipótese segundo a qual o processo de supranacionalização das migrações e da identidade comum na UE perpetua os elementos da colonialidade devido à concepção fortemente racial que contemplam que separa os ex-colonizadores dos ex-colonizados por meio de linhas abissais.

Assim, a primeira parte do presente trabalho confrontará, a partir de uma revisão na literatura, a promessa europeia de integração regional quanto à igualdade e à alteridade com as estruturas coloniais de poder, de saber e do ser quanto à raça e a própria conformação do pós-nacional europeu. Em seguida, a segunda seção pretende apresentar a política migratória 
e a política cultural da União Europeia, a partir da análise de documentos oficiais (Conclusões, Decisões, Comunicações, Diretivas, etc.) das instituições supranacionais. Por fim, a última parte demonstrará, a partir do resumo dos direitos e das restrições expostas, e a partir de uma reflexão abordagens decoloniais (e outras complementares), como a colonialidade do ser é reproduzida em escala supranacional, a partir da análise de cada "casta" classificação social entre europeus e não-europeus.

\section{A Colonialidade do Ser, Hierarquizações e as Linhas Abissais}

A situação de exclusão e de hierarquização que acomete imigrantes do Sul Global na União Europeia (UE) atesta para a perpetuação dos processos de colonialidade que se mantém devido ao apoio de estruturas de poder que se escoram em normas e instituições.

O sistema de poder colonial encarregou-se de dividir o mundo em dois lados por meio de linhas abissais ${ }^{3}$ que afasta o Norte desenvolvido e moderno do Sul considerado pobre e modernizável. A característica principal desse mundo cindido por traços abissais é a impossibilidade de coexistência dos dois no mesmo território ou lado da linha. (SANTOS, 2009)

A supremacia do Norte calcada em diferentes hierarquias que se enredam e formam um "sistema-mundo patriarcal/capitalista/colonial/moderno/europeu" (GROSFOGUEL, 2009), posicionou o homem branco heterossexual europeu no topo de uma cadeia de direitos e privilégios, enquanto que o lado de lá ficou reservado às subjetividades consideradas bárbaras, ignorantes, desprovidas de autonomia e de saberes "modernos", portanto passíveis de serem colonizadas e rechaçadas.

Consoante assevera Aníbal Quijano (2005), o principal determinante para o estabelecimento desse sistema-mundo colonial/moderno foi o padrão de poder baseado na construção da categorias de "raça" que derivou do encontro do colonizador com o diferente, primeiramente na chegada às Américas, que possibilitou a codificação dos seus próprios atributos - que incluem traços fenotípicos, cultura e civilização - como superiores. Neste momento dá-se a invenção da América Latina e, num mesmo movimento, o poder capitalista emergente identificou-se como Europa (QUIJANO, 2007). Após o surgimento das identidades racializadas do índio, e posteriormente o negro, com a colonização da África,

\footnotetext{
${ }^{3}$ No presente artigo, utiliza-se a concepção de Boaventura de Sousa Santos de linhas abissais (SANTOS, 2009) para introduzir a divisão de antigas "Metrópoles" e antigas "Colônias" e suas relações de poder, exploração e exclusão que permanecem com a chamada colonialidade.
} 
como identidades homogêneas, esse processo de identificação constituiu também o português, o espanhol, e, mais tarde, o europeu.

A classificação da raça serviu para distinguir o dominador do dominado (QUIJANO, 2005). As raças que, até esse período eram utilizadas como uma categoria taxonômica da Biologia (PERSAUD, 2002), passaram a ser consideradas como instrumento de perpetuação de assimetrias societais entre diferentes culturas, e, dentro delas, entre diferentes classes econômicas (LISBOA, 2014). A "racialização da raça", e, por conseguinte da etnia ${ }^{4}$, foi sujeita à mediação de atores dominantes e práticas discursivas que ressaltaram a diferença: questões morfológicas, comportamentais, culturais, linguísticas, de gênero e sociais (PERSAUD, 2002).

Aliado às diferenças raciais/racializadas, a colonialidade situou os saberes em hierarquias (LANDER, 2000). A detenção do poder possibilitou os europeus a qualificar seus conhecimentos como superiores (DUSSEL, 2000) e a impor os ditames da modernidade e seu ritmo como o caminho necessário ao desenvolvimento socioeconômico (CASTRO-GÓMEZ, 2007). A modernidade seria aquilo que naturalmente os europeus já haviam conquistado: a superação de um estado de imaturidade por meio do esforço crítico da razão calcada em marcos epistemológicos e históricos "universais" como a filosofia greco-romana, o Renascimento e o Iluminismo (DUSSEL, 2000). Assim, a "constituição colonial dos saberes, das linguagens, da memória e do imaginário" configurou o que o autor venezuelano Edgardo Lander (2000) chamou de "colonialidade do saber".

A racionalidade, ou o julgamento de sua ausência, é elemento que determina a nãohumanidade (BRAGATO, 2016). As percepções de mundo, os modos de pensar e de se relacionar divergentes aos europeus deram ensejo à supressão das liberdades de povos nãoeuropeus. "Ao invés de direitos, passaram a se impor repressão, negação e contenção disciplinar" (BRAGATO, 2016, p. 1810).

As subjetividades não-modernas por supostamente serem vulneráveis ao estado de natureza hobbesiano tornam-se, assim, suscetíveis de serem "civilizadas". Desta forma, era justificado o uso da violência contra o sujeito não civilizado por não estar incorporado ao pacto social. A carência de racionalidade em corpos racializados estaria intimamente ligada à ausência do ser. Em outros termos, o sistema moderno/colonial após identificar e diferenciar

\footnotetext{
${ }^{4}$ Por etnia, ou comunidade étnica, entende-se uma dada população com elementos de ascendência e procedência comum, que compartilham mitos, história e aspectos culturais comuns como língua e comportamentos (SMITH, 1993).
} 
corpos, e negligenciar as capacidades cognitivas e conhecimentos dos povos racializados, tratou de subjugar a humanidade do não-europeu. (MALDONADO-TORRES, 2007)

Desse modo, distinta das categorias anteriores, colonialidade do poder e do saber, o filósofo Nelson Maldonado-Torres (2007) propõe a retomada do termo "colonialidade do ser" de Walter Mignolo. É dizer que a colonialidade sujeita o não-europeu a uma suspeita constante em relação à sua humanidade. (MALDONADO-TORRES, 2007).

É a partir da colonialidade do ser que o presente trabalho se propõe a analisar subalternização e o afastamento de corpos no espaço geográfico da União Europeia. O nãoeuropeu/não-ocidental - imigrante ou refugiado do Sul Global - está sujeito a uma suspeita constante de sua humanidade, o que o transforma em um ser indesejável.

Esse ceticismo misantrópico (MALDONADO-TORRES, 2007) está diretamente relacionado ao que o autor franco-argelino Abdelmalek Sayad (2004) chama de "pensamento de Estado": a imigração é vista como uma ofensa ao cidadão nacional, e o imigrante carrega uma culpa intrínseca por esse primeiro "erro": o de migrar. O sujeito migrante é culpado por que o pensamento de Estado induz o sujeito nacional à um processo de autorreflexão sobre si mesmo e sobre seu Estado. Ao questionar a essência do Estado, o elemento da imigração contesta a percepção do Estado sob si mesmo (SAYAD, 2004). Como a Nação é, por si só, um discurso hegemônico, em que forças competem para representá-lo a partir de mitos, as migrações podem ser vistas como uma ameaça ao "nacional", inclusive aos cidadãos nacionais. Nesse sentido, é esperado do imigrante um comportamento aquém daquele permitido ao próprio cidadão nacional: deve ser mais polido, deve ter boas maneiras e deve ser "neutro" em relação às questões políticas. Uma vez transgredido esse estado de "amistosidade" que o imigrante deve respeitar, ele é culpado duplamente: por uma possível infração e pelo crime original de deslocar-se ao território que "não lhe pertence" (SAYAD, 2004).

O imigrante do Sul é hostilizado a partir da mediação de atores dominantes e de práticas discursivas que ressaltam a diferença fundada em um ou mais atributos: comportamentos culturais, idioma utilizado para se comunicar, práticas religiosas, traços fenotípicos, entre outros. A colonialidade, ou o colonizador, desapropria passados culturais e impõe comportamentos tidos como emancipados aos coloniais/colonizados.

Em contradição, no lado da linha visível identificado como a antiga metrópole, há um projeto de integração regional, que comemora sua maior vitória: o maior período de paz na 
historiografia da Europa. Um feito que atravessa 60 anos, graças a um projeto onde pessoas, bens, serviços e capitais, em tese, podem se mover livremente.

Ao longo dos anos, a UE tem entoado o discurso da integração regional como mola propulsora de uma educação para a paz vocacionada para a propagação de ideias antidiscriminatórias, antirracistas e para o fomento crescente da diversidade. $\mathrm{O}$ mote "Unidade na diversidade" traduz-se no intenso esforço das Instituições europeias supranacionais em produzir uma ideia de identidade e valores comuns face a enorme diversidade interna ao bloco como pressuposto para a coesão e desenvolvimento.

No entanto, quando se refere à circulação de cidadãos provenientes de países do Sul Global, nota-se um processo contínuo de criminalização de corpos que procuram melhores condições de vida, indo de encontro às normativas internacionais que consideram a migração como um direito humano.

Os direitos migratórios - livre circulação, residência e trabalho - estão agrupados no bojo da chamada cidadania europeia. O status de cidadão distingue o imigrante irregular do nacional europeu ${ }^{5}$. Tal hierarquização de pessoas foi a forma encontrada pelas Instituições supranacionais de conciliar os ímpetos coloniais dos Estados europeus membros, com a aclamação de seus princípios fundamentais de liberdade, igualdade e fraternidade. Assim a invenção da "cidadania europeia", como será visto a seguir, tem se distanciado da ideia de inclusão e, sendo discriminatória, afasta-se cada vez mais dos direitos humanos (DAUVERGNE, 2016).

O movimento do ex-colonizado rumo às sociedades metropolitanas, ou seja, ao outro lado da linha abissal (SANTOS, 2009), é tido como uma intromissão ameaçadora ${ }^{6}$. O movimento dessas pessoas traz consigo os contornos das linhas abissais, configurando o que Santos chama de uma cartografia confusa. Por sua vez, essa nova conformação cartográfica não poderia deixar de gerar práticas confusas, tal qual a desfiguração da regulação/emancipação pela lógica da apropriação/violência (SANTOS, 2009).

Em relação ao imigrante e ao refugiado, pode-se dizer que no domínio do conhecimento, a apropriação/violência vai desde a assimilação de conhecimentos e pessoas como próprios da metrópole (SANTOS, 2009), como o caso da fuga de cérebros, à proibição

\footnotetext{
${ }^{5}$ No contexto do presente artigo, "identidade europeia", "cidadania europeia" e "nacional europeu" referem-se estritamente aos nacionais dos Estados-Membros da União Europeia e conforme entendimento da política de cidadania formulada pela própria $\mathrm{U}$ E.

6 “Aqui reside a grande transgressão, pois o colonial do período colonial clássico em caso algum poderia entrar nas sociedades metropolitanas a não ser por iniciativa do colonizador (como escravo, por exemplo)" (SANTOS, 2009, p. 34).
} 
do uso de linguagens próprias em espaços públicos. Além disso, há a conversão e destruição de símbolos e lugares de culto, e a aplicação de todas as formas de discriminação cultural e racial. No campo do Direito, a lógica da apropriação/violência revela-se num apartheid social regularizado, e em diferentes formas de assimilação forçada (o imigrante, mesmo regular, integra-se ou é deportado), detenção e trabalho forçado (àqueles que estão mais à margem).

Ao avançarem as linhas epistemológicas e jurídicas à metrópole, configura-se um novo regime no qual é concomitante à atuação da lógica da regulação/emancipação e da apropriação/violência. $\mathrm{O}$ efeito da superposição da primeira pela segunda, é descrita pelo autor português como "a ascensão do fascismo social, um regime social de relações de poder extremamente desiguais que concedem à parte mais forte o poder de veto sobre a vida e o modo de vida da parte mais fraca" (SANTOS, 2009, p. 37, grifo nosso).

Esse "fascismo social" se revela de diferentes formas e coexiste com a democracia política liberal, incluindo seus valores como o respeito aos direitos humanos. Pode ser descrito também por relações contratuais nas quais o lado mais fraco é obrigado a se submeter ao poder do mais forte - como o imigrante irregular na União Europeia, que se submete às leis nacionais e supranacionais do espaço. Dessa forma, coexistem espaços de integração e de exclusão sem a pena do primeiro pelo segundo (SANTOS, 2009).

$\mathrm{Na} \mathrm{UE}$, desse modo, as ações tomadas pelas Instituições supranacionais em conjunto àquelas decididas regionalmente por Estados Nacionais, ainda atuam fortemente ancoradas na reprodução da lógica da colonialidade.

Nessa linha de raciocínio, avança-se para a segunda constatação: a supranacionalização das políticas migratórias da UE ancoradas na concepção da colonialidade do ser, resultam em uma formação de um sistema político-jurídico que incita a discriminação da pessoa humana em sua essência. Desse modo, normaliza-se uma situação de Estado de exceção, ou de eventos extraordinários anti-éticos que acontecem na guerra (MALDONADOTORRES, 2007). Como será visto a seguir, essas políticas coexistem com a chamada "cidadania europeia" e abarcam aspectos de controle de fronteiras, migrações regulares e irregulares, integração de imigrantes, refúgio e a atuação da UE em política externa.

\section{Do Lado de Cá - a União Europeia, o Estado Nacional e a Cidadania Europeia}

Preliminarmente, é necessário advertir que a proposta de formação da designada "cidadania europeia" está intimamente ligada com os objetivos do projeto da integracionista 
europeu que foi posto em prática com a intenção solucionar os problemas gerados pelo Estado Nacional.

Em primeiro lugar, estava o problema da Guerra. Para resolvê-lo seria forçoso minar o auto-interesse dos Estados que operavam num sistema internacional anárquico. Para tal, os Estados deveriam ceder parcelas de soberania para a entidade supranacional para gerar interdependência econômica, política e social, impedindo decisões unilaterais por parte dos Estados. Em segundo lugar, no plano nacional, a supranacionalização viria a resolver problemas relacionados à democracia e à justiça. De um lado, a preocupação com o ressurgimento de regimes totalitaristas - Nazismo e Fascismo - calcados em nacionalismos exaltados que trouxeram à tona violações massivas de Direitos Humanos durante a Segunda Guerra. De outro, a preocupação com a expansão do comunismo no leste europeu, ameaçando as ideais de uma democracia liberal.

Esses processos ocasionariam a formação de uma comunidade na qual o Estado Nação estaria fortificado externamente, enquanto estaria a se gerar um ambiente interno em que se transcenderia o próprio Estado-Nação ao transferir suas lealdades a um ente político com jurisdição sobre esses Estados (HAAS, 1961).

Para os autores pós-nacionais e cosmopolitas como Anthony Giddens, David Held, Mary Kaldor, Jürgen Habermas e Ülrich Beck, a proposta de integração europeia seria a única forma de contornar os erros morais intrínsecos ao Estado Nacional - como racismo, xenofobia e a intangibilidade de cumprimento dos Direitos Humanos - e resolver os diversos desafios da globalização, como as próprias migrações (HANSEN, 2009).

No entanto, autores críticos como Chris Shore (1996), Peo Hansen (2009), Necati Polat (2010) e Christian Borg (2015), questionam a conformação do supranacional como um processo em que automaticamente os impulsos nacionalistas internos seriam superados. Para Shore (1996), a superação de nacionalismos internos dependeria de processos legislativos e de decisões a cargo dos Estados e de suas lideranças políticas. Não se poderia esperar benevolência automática por conta da integração regional, nesse sentido. $\mathrm{O}$ interesse comum dos Estados Nacionais poderia resultar tanto em processos mais restritivos quanto na adoção de políticas consideradas “cosmopolitas” (HANSEN, 2009).

No meio do caminho, os indícios de déficit democrático provocaram a necessidade de gerar coesão entre os povos. Para tal, a estratégia dos atores envolvidos foi a de recorrer a um princípio semelhante ao que culminou com a criação do Estado Nacional: a ideia de pertencimento por meio da emancipação política do sujeito tornando-o cidadão do país, aliada 
à invenção de mitos de ascendência e procedência comuns, e simbologias de exaltação da pátria (HABERMAS, 2002). Assim surgiu a ideia de "cidadania europeia" com os mesmos elementos que constituíram a "cidadania nacional"7.

Assim, a cidadania europeia foi formada mediante uma estrutura legal - que concebeu e comunicou direitos especiais (DAUVERGNE, 2016) - e uma estrutura simbólica, de "identidade europeia"- que construiu simbologias, atividades e instituições para conformar um imaginário popular e evocar a "cultura europeia" com base em história e valores comuns dos povos europeus (SHORE, 1996).

Para isso, segundo o professor neozelandês Chris Shore (1996), a então Comunidade Europeia embarcou em uma série de iniciativas em torno da década de 1980. O primeiro documento foi o Relatório Tindemans sobre a União Europeia (TINDEMANS, 1976), que cunhou a expressão "Uma Europa de Cidadãos", e em seguida a Declaração do Conselho Europeu de Stuttgart de 1983, que juntas assinalaram a necessidade de cooperação entre os Estados Membros (EMs) na área cultural para dar visibilidade ao "patrimônio comum" como um elemento da identidade europeia ${ }^{8}$. (SHORE, 1996).

Ainda na mesma década começaram a florescer propostas para a criação de uma ideia de identidade no bloco (SHORE, 1996) ${ }^{9}$. E, logo, foi propalada a necessidade de facilitar a livre circulação de pessoas, um direito especial do cidadão europeu, a partir da redução de burocracias entre os EMs. Para isso, foi proposta a simplificação de processos de permissão de residência e trabalho, bem como a validação recíproca de diplomas universitários e qualificações profissionais (ADONNINO, 1985). E, na sequência, sugeriu-se uniformização das eleições parlamentares, permitindo que todos os cidadãos europeus pudessem votar independentemente se estivessem em seu país de origem ou em outro Estado Membro. Outra medida importante adotada, seguindo as sugestões, foi a permissão de votação em eleições locais (Municípios e Municipalidades) fora do país de origem do cidadão. Por último, foi

\footnotetext{
${ }^{7}$ Observa-se que a União Europeia configura-se como um espaço multifacetado, considerado como um modelo de regionalismo complexo que comporta um sistema de geometria variável (espaço), um sistema de múltiplas velocidades (tempo), e um de integração a la carte (matéria). Estes eixos reconhecem, em algumas matérias, a possibilidade de diferentes estruturas, diferentes níveis e tempos de progressão, permitindo uma gradual adesão de realidades diferentes à União, com o compromisso comum da integração e sem impedir seu aprofundamento do bloco. Dois exemplos clássicos são a zona Schengen e a Zona Euro que são formadas por alguns Estados que não fazem parte da UE e que alguns países do bloco não fazem parte. Neste sentido, consultar: SILVA, 2013.

${ }^{8}$ Esses documentos estrearam um novo quadro de ações das instituições supranacionais da União Europeia como o Conselho, a Comissão e o Parlamento - em relação à cultura.

9 O Comitê ficou conhecido como Grupo Adonnino, que publicou dois relatórios em 1985 com diversas propostas sobre artes, mídia, informação, educação, turismo, esporte e patrimônio, grande parte votadas e incorporadas pelo Conselho nos anos seguintes.
} 
concedido o direito de liberdade de expressão e de assembleia a todos os cidadãos da UE, independente de onde estejam residindo dentro de seu território (ADONNINO, 1985)

A adoção por parte das instituições europeias desse pacote de direitos ${ }^{10}$ culminou com o que se chama atualmente de "cidadania da União Europeia", ou popularmente "cidadania europeia" que ganhou vigência com o Tratado de Maastricht de 1992. Catherine Dauvergne (2016) advoga que a cidadania europeia é primariamente uma categoria imigratória, pois o apanhado de direitos especiais que ela concede centralizam-se principalmente no campo das migrações. Nessa categoria, inclui-se a livre circulação, o direito à residência e ao trabalho.

Esta ideia de direitos especiais baseia-se na concepção de que além dos direitos concedidos de acordo com o Estado Nacional de origem, a cidadania da União Europeia garante direitos complementares $^{11}$ que não substituem a cidadania nacional ${ }^{12}$. A evolução dessas propostas, no que tange à cidadania, resultou no que hoje se têm como "os Direitos dos cidadãos da UE”, consagrados na segunda parte do Tratado sobre o Funcionamento da União Europeia (JO, 2012) e no capítulo V da Carta dos Direitos Fundamentais da União Europeia (JO, 2000).

Nesse sentido, a inserção da ideia de um cidadão europeu, sujeito a direitos especiais, é semelhante ao processo de emancipação do sujeito na criação do Estado Nacional. Para Habermas (2002), essa teria sido a solução do elemento Nacional: promover a integração e a legitimidade de uma entidade superior com base no apelo ao pertencimento a um passado histórico, e o compartilhamento de um futuro ao colocar o cidadão no centro da tomada de decisões dessa entidade.

Deve-se observar também que para a perspectiva colonial, num "duplo movimento histórico" (QUIJANO, 2005, p. 119) a colonização e a formação do Estado Nacional foram responsáveis por generalizar e identificar raças, além de emancipar alguns sujeitos, forjando hierarquias de saberes e seres. O estabelecimento do Estado-Nação europeu seria, para

\footnotetext{
10 Além do direito à liberdade de circulação e de residência na UE, sem discriminação em razão da nacionalidade, e do direito de eleger e de ser eleito em eleições nacionais, o cidadão europeu possui os seguintes direitos: Direito de petição; Direito de apresentar uma queixa ao Provedor de Justiça; Direito a proteção consular para cidadãos da UE sem representação diplomática e o Direito de solicitar à Comissão que proponha nova legislação

11 "Segundo o artigo 17 do Tratado da Comunidade Europeia (TCE), é cidadão da União qualquer pessoa que tenha a nacionalidade de um Estado-membro; a cidadania europeia acresce à cidadania nacional e não a substitui" (DE MOURA, 2009, p. 130).

${ }^{12}$ Smith (1991) explica que é perfeitamente possível a manutenção por um indivíduo ou grupo de indivíduos de mais de uma identidade étnica/nacional. Nesse sentido, a inserção de um sentimento nacionalista europeu não exclui os nacionalismos internos.
} 
Quijano, um processo semelhantemente colonizador e violento ${ }^{13}$, forçando homogeneidade interna a partir do que se chamou de identidade nacional. Assim, o sistema internacional foi estabelecido com o centro na Europa Ocidental, uma vez que a evolução do Estado seria um fenômeno exclusivamente europeu.

A cidadania comum é uma prova que a UE passou a recorrer a soluções nacionalistas para promover a superação de problemas comunitários e garantir o fortalecimento do processo de supranacionalização. A resposta para problemas estatais seria cada vez mais integração (HANSEN, 2009), numa esperança de formalizar uma cidadania exclusivamente formada por uma estrutura cívica.

No entanto, a cidadania europeia foi crescentemente atrelada à uma estrutura simbológica composta por bandeira, hino, selos com os "pais fundadores" da União Europeia, como Robert Schuman e Jean Monnet, e a adoção de um passaporte comum ${ }^{14}$.

Além disso, a evocação de um patrimônio comum e futuro compartilhado se tornaram frequentes nos discursos da Comissão Europeia que ressaltam que a "identidade europeia é resultado de séculos de História comum e o compartilhamento de valores fundamentais e culturais [...]." (COMMISSION, 1988, p. 5, tradução nossa, destaque nosso) e que "unidade na diversidade, o respeito pela diversidade cultural e linguística e a promoção de um património cultural comum estão no cerne do projecto europeu”. (COMISSÃO, 2007, p. 01, destaque nosso). E, ainda segundo a Comissão:

\begin{abstract}
"o património cultural material e imaterial da Europa é a nossa riqueza comum - a herança que nos foi legada pelas gerações anteriores de europeus e aquele que será o nosso legado às gerações vindouras. Constitui um repositório insubstituível de conhecimentos e um recurso precioso para o crescimento económico, o emprego e a coesão social. (...) O nosso património cultural e a forma como o preservamos e o valorizamos são fatores que determinam o papel da Europa no mundo e a atração que exerce como lugar para viver, trabalhar e visitar. (COMISSÃO, 2014, p. 02, destaque nosso)
\end{abstract}

Assim, a UE tem replicado símbolos e elementos nacionalistas em âmbito supranacional para ressaltar a ideia de unidade na diversidade. Ademais, a cidadania europeia

\footnotetext{
13 “O Estado-nação iniciou-se como um processo de colonização de alguns povos sobre outros que, nesse sentido, eram povos estrangeiros. Em alguns casos particulares, como na Espanha que se constitua sobre a base da América e de seus enormes e gratuitos recursos, o processo incluiu a expulsão de alguns grupos, como os muçulmanos e judeus, considerados como estrangeiros indesejáveis. Esta foi a primeira experiência de limpeza étnica no período moderno" (QUIJANO, 2005, p. 119).

${ }^{14}$ Outras propostas incluíam datas comemorativas - como o 9 de Maio como o Dia da Europa -, e Anos Europeus promovendo atividades em áreas específicas (Língua, Direitos Humanos, Patrimônio Cultural, entre outros). Além dos direitos de cidadania, o incentivo à cultura e ao Ensino foram crescentes nas políticas de integração cultural, permitindo o jovem europeu o acesso a museus gratuitos, e um crescente fomento à intercâmbios culturais e estudos de línguas oficiais e minoritárias. No esporte, foram fomentados campeonatos europeus e a utilização da bandeira da União Europeia em uniformes de times (ADONNINO, 1985).
} 
cumpre um propósito principal de facilitar atividades econômicas ligadas à livre circulação às migrações internas. Para Dauvergne (2016), a nova identidade europeia serve como um processo de finalização da "culpa colonial", na medida em que a ideia de "Uma Europa", nova e unida, se distancia do passado colonial dos países europeus, abrindo uma era "pós-póscolonial". Nessa nova era, a culpa colonial é redirecionada aos erros do Estado Nação, trazendo uma era não mais "pós-colonial", mas forjadamente "pós-nacional". O modelo supranacional europeu teria superado esses erros, livrando assim seus EMs de suas responsabilidades em relação a seus passados colonizadores.

Consequentemente, junto à formação da cidadania europeia, houve um processo de repriorização das migrações, eliminando aos poucos as migrações coloniais, principalmente advindas dos países explorados na África (DAUVERGNE, 2016). Esse processo resultou em um campo de atuação contrário ao das políticas culturais e identitária, pois, a harmonização das políticas de migração e de refúgio alinharam-se cada vez mais com a lógica colonial da apropriação/violência. Mas além disso, a identificação do europeu da União Europeia, tanto em estruturas legais quanto simbólicas, resultou em processos semelhantemente discriminatórios, gerando uma evidente estrutura hierárquica que diferencia europeus de nãoeuropeus a partir de normas supranacionais.

Dado o exposto, observa-se que a regularização migratória da UE não pode ser dissociada da política cultural e identitária para a chamada "cidadania europeia". É sua contraposição, pois, como coloca Santos (2009) uma vez estabelecido um espaço interno de livre circulação, trabalho e residência, a exigência de uma sub-humanidade moderna serve como condição para sua própria existência. A diferença com o passado, no entanto, é que o antigo colonial trespassa o espaço físico do colonizador, bagunçando a cartografia de linhas abissais. E acrescenta: "Uma cartografia confusa não pode deixar de conduzir a práticas confusas. A regulação/emancipação é cada vez mais desfigurada pela presença e crescente pressão da apropriação/violência no seu interior" (SANTOS, 2009, p. 35).

A exclusão sistemática de imigrantes classificados como não-comunitários ocorre sem a suspensão da cidadania europeia que comporta uma série de direitos alinhados a liberdades fundamentais e direitos humanos. Conforma-se, assim, um Estado de exceção, no qual as restrições dos direitos democráticos estão "sob o pretexto da sua salvaguarda ou mesmo expansão (SANTOS, 2009, p. 35).

Nos países da UE, as migrações passaram de um quadro de incentivo por razões econômicas e pós-coloniais, ao afastamento de imigrantes e refugiados mediante a construção 
de um espaço de segurança, policiamento e justiça. O estabelecimento e alargamento da Zona Schengen $^{15}$ supranacionalizou o tratamento das migrações irregulares e as questões de refúgio, ou seja, os Estados concederam cada vez mais competências decisórias desses assuntos à União. No decorrer desse processo, as migrações regulares - econômicas e familiares - tornaram-se matérias pouco harmonizadas pela UE, enquanto as migrações irregulares e o refúgio configuraram um sistema bastante desenvolvido e unificado (HAMPSHIRE, 2015).

Até a década de 1990, a cooperação na área das migrações entre os Estados-Membros ocorria de forma temporária e intergovernamental (HAMSPHIRE, 2015). Ao caminhar para uma “política de zero migrações” (MARTINIELLO, 2009, tradução nossa), quando os Estados optaram por eliminar todas as formas de incentivo às migrações, as Instituições da União Europeia encontraram um campo para a integração em matéria de migrações.

Dauvergne (2016) destaca que esse processo ocorreu graças ao novo perfil ${ }^{16}$ atribuído aos Estados-Membros nas décadas finais do século XX - tornando-se estatisticamente países de imigração. Os fluxos migratórios no pós Segunda Guerra Mundial (1947-1960) foram atraídos por cenários de necessidades de reconstrução da Europa e atrair de mão-de-obra para suprir a demanda da indústria pesada e da mineração (MARTINIELLO, 2009). No entanto, alguns países sofriam com altas taxas de desemprego, como Itália e Espanha, o que levaram a nações como Alemanha e Bruxelas a convidarem trabalhadores do Sul da Europa, dos Balcãs, do Norte da África e da Turquia (MARTINIELLO, 2009). Atrelado a isso, os antigos países colonizadores passaram por um breve momento de retratamento com suas antigas colônias, permitindo formação de quadros de migrações de ex-colonizados e o retorno de excolonizadores, como o fluxo de argelinos em direção à França e nacionais franceses colonizadores retornando à terra natal (MARTINIELLO, 2009).

No entanto, Dauvergne (2016) argumenta que crescentemente os impérios colonizadores entraram em rota de finalização de suas responsabilidades com as ex-colônias,

${ }^{15}$ O Acordo de Schengen foi assinado em 14 de Junho de 1985 com o propósito de suprimir gradualmente os controles nas fronteiras internas e instaurar um regime de livre circulação para os nacionais dos Estados signatários e de países terceiros. A Convenção de Schengen, que entrou em vigor em 1995, complementa o Acordo, define os termos de aplicação e estabelece as garantias relacionadas à livre circulação. O Acordo e a Convenção de Schengen, as normas adotadas com base nestes dois textos e os acordos conexos formam o "acervo de Schengen", que foi integrado ao quadro institucional e jurídico da União Europeia em decorrência de um protocolo anexo ao Tratado de Amsterdã. A Zona é formada atualmente por 26 Estados e prevê direitos de livre e irrestrita circulação e de residência para os cidadãos dos Estados signatários.

16 Segundo a autora, uma nova política migratória é conformada com o fim das chamadas sociedades de povoamento (em inglês, settler societies), na qual os antigos colonizadores agora tornam-se destino das migrações, principalmente de fluxos Sul-Norte (DAUVERGNE, 2016). 
principalmente em matéria de migrações. Com o novo perfil de países de imigração, e com a política de zero migrações, a harmonização de políticas supranacionais se tornou medida efetiva para desresponsabilizar os antigos colonizadores. A partir de 1990, torna-se nítida a tentativa de afastar cada vez mais imigrantes do sul global. Marco Martiniello (2009) adiciona que a concessão de parcelas de soberania em matéria de migrações e asilo só foi possível por que as políticas foram cada vez mais restritivas.

Uma das políticas mais controversas estabelecidas em matéria de asilo surgiria em 1990 com a Convenção de Dublin (JO, 1997) que determinou a responsabilidade do primeiro Estado de entrada do requerente de prover o asilo. Sua disposição mais restritiva ${ }^{17}$ possibilita o retorno forçado do solicitante de refúgio ao Estado responsável pela análise do pedido - que deve ser o Estado cujo território o solicitante adentrou o território comunitário.

Hoje, a estrutura legal do sistema comum de asilo e de migrações legais (ou regulares) está concentrada no Tratado de Lisboa de 2007, de modo que

Governos nacionais retém o direito de decidir quantos imigrantes de fora da UE querem admitir, mas quase todo aspecto da migração (migrações econômicas, refúgio, controle de fronteiras, integração) - de dentro e de fora da Europa - tem uma dimensão supranacional (HAMPSHIRE, 2015, p.1, tradução nossa).

Desse modo, o estabelecimento de um Sistema Europeu Comum de Asilo (SECA) (COMISSÃO, 2014), a Diretiva do Retorno (JO, 2008); a criação de um instrumento de controle de fronteiras, representado pela Agência Europeia da Guarda de Fronteiras e Costeira (Frontex) (JO, 2004); a atuação internacional a partir da Abordagem global para a migração e a mobilidade (GAMM) (COMISSÃO, 2011); o Sistema Eurodac para recolhimento e comparação de impressões digitais, podendo ser utilizado para, por exemplo, efeitos da aplicação da Convenção de Dublin (JO, 2000) e investigações criminais da Europol; e outros dispositivos, explicitam toda a restritividade da harmonização de políticas migratórias na União Europeia.

O SECA, por exemplo, é composto por uma série de Diretivas que, ao invés de expandirem e detalharem condições de proteção e acolhimento, restringem e violentam o solicitante de refúgio. Na Diretiva de Condições de Acolhimento (Diretiva 2013/33/UE), por exemplo, existe a possibilidade de detenção de solicitantes de asilo com base em disposições

\footnotetext{
${ }^{17}$ Em seu Artigo 20 , Inciso 7, a Convenção estabelece: “O Estado-membro ao qual foi apresentado o pedido de asilo é obrigado, nas condições previstas no artigo $13^{\circ}$ e com vista à conclusão do processo de determinação do Estado responsável pela análise do pedido de asilo, a retomar a cargo o requerente de asilo que se encontre noutro Estado-membro e que neste tenha apresentado um pedido de asilo depois de ter retirado o seu pedido durante o processo de determinação do Estado responsável”. (JO, 1997, p. 3).
} 
extremamente subjetivas ou obscuras como "se houver risco de fuga do requerente", e "se a proteção da segurança nacional e da ordem pública o exigirem", ou "para determinar ou verificar a respetiva identidade ou nacionalidade" (JO, 2013, p. 6). Além da detenção, a livre circulação de solicitantes pode ser circunscrita pelo Estado-Membro de acolhida "no interior de uma área que lhes for fixada por esse Estado-Membro"18 (JO, 2013, p. 6).

Para pessoas migrantes consideradas irregulares, a Diretiva do Retorno (Diretiva 2008/115/CE) impõe a retirada "voluntária" do país entre 07 e 30 dias, e após isso propõe padrões de retorno dessas pessoas ao seus países de origem. Há também a possibilidade de detenção pelo "crime" de migrar, que deve se estender a um período de no máximo seis meses, e prorrogáveis por mais 12 meses em "casos específicos", segundo disposições da Diretiva (JO, 2008).

$\mathrm{Na}$ qualidade de ator de política externa a UE complementa o controle das migrações a partir da Abordagem global para a migração e a mobilidade (GAMM). Criada em 2005 e adaptada em 2011, a GAMM é um quadro geral para o estabelecimento das chamadas parcerias de mobilidade com países não-membros (COMISSÃO, 2011). A ideia principal é reforçar o controle dos fluxos em troca de apoio a projetos internos voltados ao desenvolvimento (e, portanto, a tentativa de eliminar "os motivos" da migração). Ademais, outros Acordos foram celebrados com o intuito de expandir a fronteira da Convenção de Dublin, isto é, determinar como Responsável pelo asilo Estados não-membros da União Europeia, a exemplo do Acordo celebrado com a Turquia em 2014 para conter a mobilidade do Oriente Médio para a Europa (JO, 2014).

Adicionalmente, as políticas restritivas e violentas escondem também a lógica da apropriação. Nesse sentido, desenvolveram-se, também, dispositivos que garantem a apropriação de cérebros no espaço da União Europeia a exemplo da Diretiva Blue Card, a qual garante a pessoas "altamente qualificadas" um visto especial e direitos semelhantes ao trabalhador europeu fora de seu Estado de origem (JO, 2009).

A lógica da apropriação/violência encontra eco nos princípios de integração de imigrantes comuns, designadamente as que determinam o "respeito pelos valores fundamentais da União Europeia" (princípio 2) e o "conhecimento da língua, da história e das instituições da sociedade de acolhimento" (princípio 4) (CONSELHO, 2004, p. 15-16). Para

\footnotetext{
18 Artigo $7^{\circ}$, Parágrafo 1: Os requerentes podem circular livremente no território do Estado-Membro de acolhimento ou no interior de uma área que lhes for fixada por esse Estado-Membro. A área fixada não deve afetar a esfera inalienável da vida privada e deve deixar uma margem de manobra suficiente para garantir o acesso a todos os benefícios previstos na presente diretiva.
} 
De Luca Sebastiani (2015) esse é um mecanismo da colonialidade para dividir a experiência migratória entre leis de acesso à cidadania e a etapa de integração e para permitir o julgamento da aptidão do imigrante (SEBASTIANI, 2015). Assim, o imigrante não integrado ou é alijado no lado invisível das linhas abissais (SANTOS, 2009), ou mesmo está sujeito ao retorno ao lado de lá físico das linhas abissais.

Por fim, vale ressaltar que o fato desse processo permitir o alavancamento de interesses nacionais e das simbologias que são reiteradas do Nacional, identifica, por sua vez, não o pós-nacional ou supranacional, mas o supernacional (um alavancamento dos interesses e identidades nacionais em uma instituição superior), ou até o hipernacional (HANSEN, 2009). Em adição, a tentativa de esconder o passado colonial serve como forma de legitimar políticas restritivas contrárias aos próprios Direitos Humanos defendidos no bloco, dando menor preocupação a governos quanto sua "reputação individual, responsabilidades e obrigações internacionais" (HANSEN, 2009, p. 33, tradução nossa). Ao acumular cada vez mais competências, a União Europeia tira da mão dos Estados ex-coloniais a responsabilidade de adesão à normas mais compreensivas de refúgio e migrações.

A colonialidade do poder se revela na formulação de políticas cada vez mais excludentes e violentas que é seletiva segundo as prioridades econômicas do bloco. Os níveis de exclusão/inclusão variam de acordo com a classificação e a atribuição do status de cidadania que desnudam as linhas abissais. Estes temas serão explicitados na sequência, a partir da noção de "cartografia confusa" (Santos, 2009) e de "heterogêneas hierarquias globais" (Grosfoguel, 2009).

\section{Cartografias Confusas e a Hierarquização do Ser}

Não se pode perder de vista a raça (racializada) como um elemento de subalternização e hierarquização de corpos no mundo. A formação de identidades raciais - negros, índios, mestiços - possibilitou a perpetuação de padrões de poder no sistema internacional de Estados.

A localização espaço-temporal dessas identidades racializadas conformaria o sistemamundo capitalista (WALLERSTEIN, 2004) que, por sua vez, contempla uma estrutura de poder ainda mais ampla que colocava o branco europeu como centro. Assim, a colonização impôs uma sobreposição de diversas hierarquias de raça/etnia, gênero, sexualidade, língua, classe e espiritualidade. Ou, o que Grosfoguel (2009) chamou de "heterogêneas hierarquias 
globais", que operam de forma confusa e sobreposta, enredam-se e aplicam-se independentemente em cada situação. Para Grosfoguel, a colonialidade do poder é um enredamento de

Formas de dominação e exploração sexual, política, epistêmica, económica, espiritual, linguística e racial, em que a hierarquia étnico-racial do fosso cavado entre o europeu e o não-europeu reconfigura transversalmente todas as restantes estruturas globais de poder (GROSFOGUEL, 2009, p. 392).

A hierarquia étnico/racial é um elemento estruturante do "sistema-mundo patriarcal/capitalista/colonial/moderno/europeu” (GROSFOGUEL, 2009, p. 392). Quijano (2005) exemplifica como, por exemplo, a atribuição de assalariamento foi primariamente um direito do branco, em contraste ao negro e ao indígena, cujos direitos de assalariamento eram negados. Hoje, da mesma forma, "o trabalho coercivo (ou barato) é feito por pessoas nãoeuropeias situadas na periferia, e o 'trabalho assalariado livre' situa-se no centro" (GROSFOGUEL, 2009, p. 392).

Como princípio organizador das demais hierarquias, a ideia de raça e etnia, e racismo, são fundamentais para entender a perpetuação da exclusão na União Europeia. É o ponto de partida para entender a "cartografia confusa" (SANTOS, 2009), elaborada a partir do avanço para o lado de cá, europeu, das linhas abissais que outrora restringiam-se a fronteiras físicas.

Essas contradições perpetuam-se na estrutura histórica da União Europeia. Enquanto a política identitária busca ressaltar a igualdade a partir do reconhecimento da alteridade entre cidadãos europeus, sua política migratória é reforçada pelo padrão colonial de poder, por intermédio de um ceticismo misantrópico (MALDONADO-TORRES, 2007) quanto às capacidades de integração da pessoa migrante, subalterizando-a.

O efeito disso é que a política identitária, a política de integração e as políticas migratórias e de refúgio aliam as contradições de discurso e prática. Ao mesmo passo que o discurso de igualdade, de antidiscriminação, dos Direitos Humanos e da "Unidade na diversidade" é reforçado, avançam as políticas violentas xenófobas, hierarquizantes e excludentes.

Afinal, do que se trata o discurso da igualdade? É a proibição, por meio do arcabouço consagrado pelo Direito da União Europeia da discriminação em matéria de raça, etnia, religião, deficiência, idade ou orientação sexual. Como exemplo, há Duas Diretivas que são basilares: a Diretiva relativa à igualdade no emprego (Diretiva 2000/78/CE) e a Diretiva relativa à igualdade racial (Diretiva 2000/43/CE). Nelas, a discriminação com base em raça se resume a situações relacionadas a traços físicos, enquanto etnia designa a discriminação 
referente a comportamentos e características comuns - língua, religião, história, descendência geográfica. Está nítido também nessas Diretivas que a não-discriminação é um direito também a nacionais de países terceiros.

Sem embargo, essa proibição não restringe o tratamento diferenciado em razão do status migratório de nacionais de países terceiros e de apátridas, como segue:

Para esse efeito, devem ser proibidas em toda a Comunidade quaisquer formas de discriminação directa ou indirecta baseada na origem racial ou étnica, nos domínios abrangidos pela presente directiva. Esta proibição da discriminação aplica-se igualmente aos nacionais de países terceiros, mas não abrange as diferenças de tratamento em razão da nacionalidade nem prejudica as disposições que regem a entrada e a residência dos nacionais de países terceiros e o seu acesso ao emprego e à actividade profissional (JO, 2000, p. 2, destaque nosso $)^{19}$.

Desse modo, pode-se assumir, nos termos empregados pelas normas comunitárias, que o princípio da não-discriminação não abrange na sua totalidade os nacionais de países terceiros. Em suma, existe legalmente uma estratificação social entre europeus e nãoeuropeus. Essa discriminação ocorre com base em nacionalidade/raça/etnia a partir do acesso individual à nacionalidade/cidadania.

O efeito desse desenho confuso, repleto de nuances e linhas abissais tênues está representado didaticamente na imagem abaixo.

Imagem: A estratificação social de direitos entre europeus e não-europeus na União Europeia

\footnotetext{
${ }^{19}$ Ambas as Diretivas, de Igualdade Racial e de Igualdade de condições de emprego, apresentam esse mesmo parágrafo em suas disposições iniciais.
} 


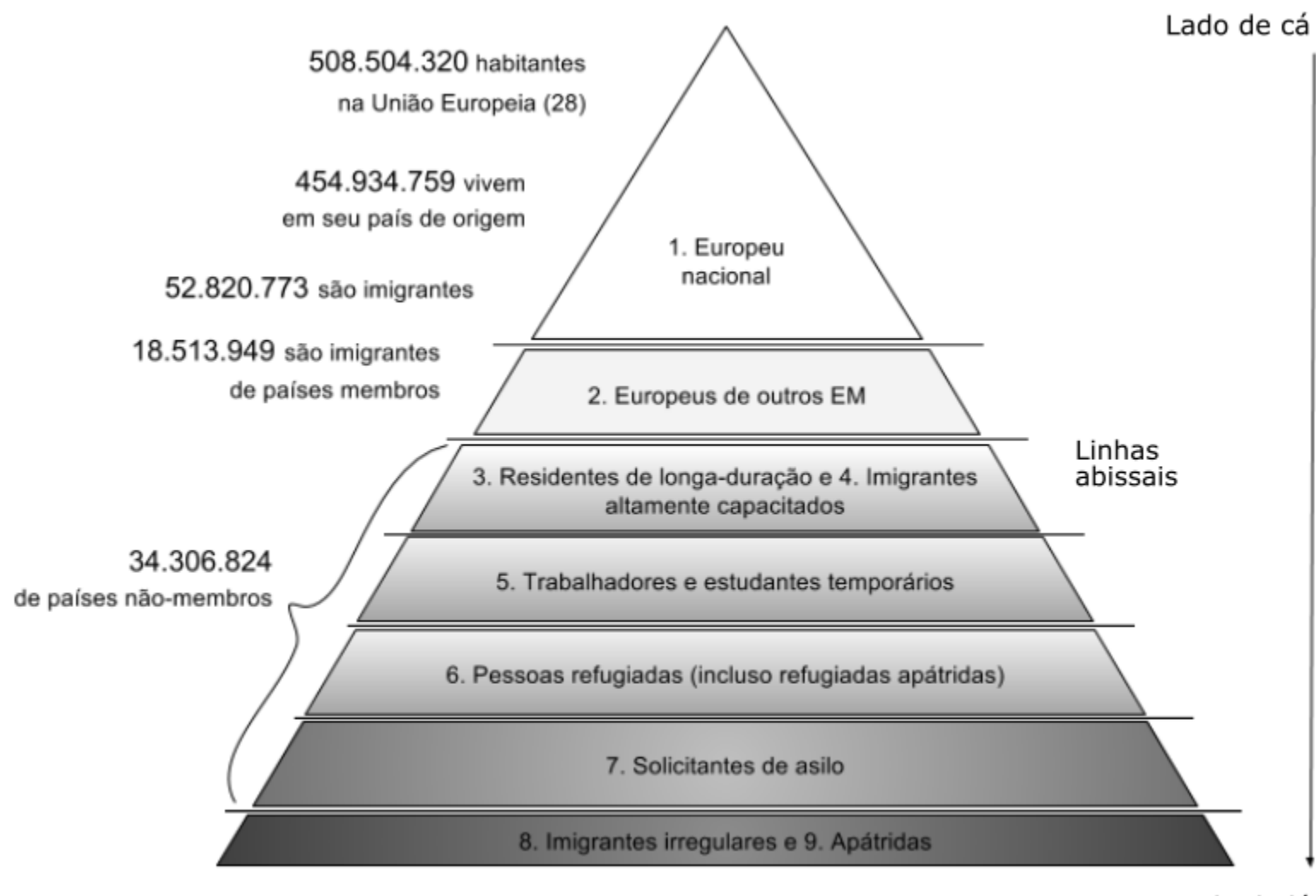

Lado de lá

1. Europeu da União Europeia Nacional que vive em seu Estado de origem; 2. Europeu da União Europeia de um EM que vive em outro EM; 3. Residentes de longa-duração segundo Diretiva 2003/109; 4. Imigrantes altamente capacitados segundo Diretiva "Blue-card" 2009/50/CE; 5. Imigrantes que são trabalhadoras/es ou estudantes e residem temporariamente em um EM, segundo Diretivas 2011/98/UE e 2014/36/UE; 6. Pessoas refugiadas (inclusive refugiados apátridas) segundo Diretiva 2011/95/UE; 7. Solicitantes de asilo segundo Diretivas 2013/32/UE e 2013/33/UE; 8. Imigrantes irregulares, que encaixam-se na Diretiva de Retorno (2008/115/CE) que também discorre sobre detenção; 9. Apátridas que não se encaixam nas disposições da Diretiva Diretiva 2011/95/UE sobre concessão de proteção internacional.

Fonte: Adaptado de (PISETA, 2017). Elaboração dos autores e dados da Eurostats de 2015

A hierarquização da tabela foi proposta a partir da alusão à categorização do "lado de cá" e do "lado de lá" das linhas abissais, proposta por Boaventura de Sousa Santos (2009). No topo desta estratificação, representada pela pirâmide acima como o número 1, estão os nacionais de EMs da Zona Schengen (COMISSÃO, 2018) que residem em seu país de origem. Estes usufruem de amplos direitos, que além daqueles elencados nas Constituições, têm acesso àqueles estabelecidos pelo Direito da UE. Dentre essas prerrogativas, estão o pleno direito à livre circulação e residência a outros países da Zona Schengen. Além disso, podem participar de eleições do Parlamento Europeu e de eleições locais, mesmo quando não residem em seu país de origem. Os direitos e vantagens que usufruem sob a égide do Direito da UE mantém-se igualmente quando migram ou viajam para outros países membros da Zona 
Schengen. Estes estão plenamente no lado de cá, são mais emancipados, gozam de privilégios ampliados com a chamada cidadania europeia.

Logo abaixo na pirâmide estão aqueles nacionais de EMs da Zona Schengen, representados pelo número 2, que residem em outro EM da mesma Zona. Estão abaixo na pirâmide por que as leis nacionais tendem a não permitir exatamente as mesmas condições entre nacionais e não nacionais, independente de qual status. A distinção nacional/estrangeiro ainda permeia as relações, principalmente quando a linguagem ${ }^{20}$ difere, dificultando a integração mesmo de europeus em território de outro Estado-Membro.

Abaixo destes estão os imigrantes altamente capacitados (3) e os de residência de longa-duração (4), que possuem quase os mesmos direitos e restrições entre si. Os imigrantes que possuem o Blue Card (Diretiva 2009/50/CE) são facilmente apropriados e integrados, têm o direito de acessar e residir em todo o território nacional em que a residência foi concedida durante quatro anos, enquanto a circulação em outros países membros limita-se a um período de três meses. Os residentes de longa-duração (Diretiva 2003/109), por outro lado, são aqueles que diante de normativas estabelecidas pelos EMs, já residem há mais de cinco anos na União e demonstram suposta capacidade de integração. A análise dessa capacidade pode permitir a residência em outro EM, de acordo com avaliação e pré-requisitos nacionais. Ambos os casos usufruem do direito à reunião familiar (Diretiva 2003/86/CE) e estendem-se as mesmas condições do imigrante - como financeiras, de alojamento e seguro de saúde - ao seu núcleo familiar.

Por sua vez, para os trabalhadores (Diretivas 2011/98/UE e 2014/36/UE) e estudantes temporários (Diretiva 2016/801/UE) (5), apesar da alocação na estratificação apresentada, as condições e direitos tendem a ser pouco restritivos. Não há o direito de residência em longa duração - em geral limita-se a um ou dois anos - mas o visto permite a livre circulação em território comunitário. Estes estão no exato limiar entre o lado de lá e o lado de cá, uma vez que por uma questão de tempo (expiração do visto) podem se tornar imigrantes irregulares. A suspeita é iminente, e passar do tempo de estada pré-estabelecido pode resultar em uma proibição de entrada por cinco anos após passível deportação e até mesmo de detenção.

\footnotetext{
${ }^{20}$ Utiliza-se aqui o sentido de linguagem de Fanon, que para o autor é a instituição social de valores, da cultura e da língua, representando a identidade: "Falar é existir absolutamente para o outro (...) é estar em condições de empregar um certa sintaxe, possuir a morfologia de tal ou qual língua, mas é sobretudo assumir uma cultura, suportar o peso de uma civilização." (FANON, 2008, p. 33).
} 
As condições passam a ser cada vez menos favoráveis na medida em que se aproxima da do lado de lá das linhas abissais. Em geral, o público refugiado (6) advém de zonas/países que os EMs e a Zona Schengen não autorizam automaticamente a entrada. Por esse motivo, a pessoa refugiada não possui o direito de livre circulação entre os demais EM além daquele em que o refúgio foi reconhecido. Diferentemente do visto Schengen (Diretiva 2016/399/UE), que autoriza a livre circulação em todos os países deste espaço, a concessão do status de refugiado não garante este direito, e, portanto, a pessoa refugiada deve permanecer no primeiro país de acolhida se assim deseja manter seu status (Diretiva 2013/32/UE).

O solicitante de asilo (7) é ainda "inferior", e suas condições podem ser bastante desfavoráveis. Com um status entre o refugiado e o imigrante irregular, eles devem ser protegidos e "não-devolvidos", ao mesmo tempo que estão sujeitos a serem confinados a determinadas áreas de um território nacional (JO, 2013). Tais áreas têm sido chamadas de "campos de refugiados" 21 , que são negativamente reconhecidos por péssimas condições de habitação, alimentação e saúde, além de dificultar ainda mais o acesso ao mercado de trabalho dessas pessoas. Os requerentes de asilo podem também estar sujeitos à restrição dos seus direitos de migração voluntária ${ }^{22}$. Em primeiro lugar, podem ser redirecionados ao primeiro país em que aportaram, segundo as disposições do acordo de Dublin (JO, 1997), sendo ou um EM ou um Estado terceiro com o qual a UE celebrou acordo, como é o caso da Turquia (CONSELHO, 2016). Soma-se a isso a possibilidade de realocação para outros EMs, mesmo que cumprindo o requisito de estadia no primeiro território de acesso, conforme as subjetivas capacidades de integração do solicitante de asilo (JO, 2015). Por último, o solicitante pode ser detido, mesmo quando não exercendo atividades ilícitas - como para comprovar sua identidade nacional ${ }^{23}$.

A base dessa pirâmide são os imigrantes irregulares (8) e apátridas sem proteção internacional $(9)^{24}$, que não possuem nenhum dos status acima, por que estão invisibilizados,

\footnotetext{
${ }^{21}$ Podem ser citados o campo de Calais (França), Kara Tepe e Piraeus (Grécia) e Roszke (Hungria).

${ }^{22}$ O direito de migrar é estabelecido na Declaração Universal dos Direitos Humanos (ONU, 1948), em seu artigo XIII: 1. Todo ser humano tem direito à liberdade de locomoção e residência dentro das fronteiras de cada Estado. 2. Todo ser humano tem o direito de deixar qualquer país, inclusive o próprio, e a este regressar.

${ }^{23}$ Em casos mais extremos, como o da Hungria, o Estado de fato confina a uma determinada área da qual os requerentes de asilo não podem sair até que tenham uma decisão final a respeito do pedido (POLITICO, 2017).

${ }^{24}$ De acordo com o Artigo $2^{\circ}$ da Diretiva 2011/95/UE, é elegível para protecção subsidiária, “o nacional de um país terceiro ou um apátrida que não possa ser considerado refugiado, mas em relação ao qual se verificou existirem motivos significativos para acreditar que, caso volte para o seu país de origem ou, no caso de um apátrida, para o país em que tinha a sua residência habitual, correria um risco real de sofrer ofensa grave na acepção do artigo 15.o , e ao qual não se aplique o artigo 17.o, n.os 1 e 2, e que não possa ou, em virtude dos referidos riscos, não queira pedir a protecção desse país”. Nos termos dessa diretiva, o apátrida que não incorre à
} 
existem apenas enquanto sujeitos de regulação social. Estes não têm direitos de livre circulação, de residência, de reunião familiar ou a qualquer outra prerrogativa com base no Direito Supranacional, ainda que sejam titulares $\mathrm{de}^{\mathrm{o}}$ direitos segundo as normativas internacionais de Direitos Humanos que a UE viola. Estas pessoas podem ser detidas por até 18 meses quando encontrados, antes de serem reenviadas (Diretiva 2008/115/CE) forçadamente a seu país de origem ou a outro Estado fora da UE. Estão na base da pirâmide por que não possuem acesso ao mercado de trabalho formal, correndo o risco de serem vítimas de trabalho forçado (incluindo trabalhos ilícitos) e exploração sexual. Quanto ao acesso a serviços públicos básicos, o incentivo da norma supranacional é nulo. Por fim, estão sujeitos à discriminação, sem a proteção das disposições das Diretivas de Antidiscriminação e de Igualdade de Condições de Trabalho, com base na sua capacidade de acesso à nacionalidade/cidadania.

A outra cara da privação de direitos e quem revela a face da colonialidade do poder é o tratamento das migrações como tema de ordem pública e de segurança nacional (SEBASTIANI, 2015). Ou seja, o imigrante, principalmente aquele irregular, que está mais centralizado no lado de lá das linhas abissais, é tratado como bárbaro, incivilizado, e portanto a violência é justificada para destruir os "obstáculos da modernização" (DUSSEL, 2000, p. 29). Exemplo disso foi a denúncia feita pelo The Guardian sobre Melilla, uma das duas fronteiras terrestres da Europa com a África ${ }^{25}$ :

\begin{abstract}
Em 1999, com o aumento da resistência da UE às migrações, a cidade ergueu uma intimidante nova barreira - duas cercas paralelas de $4 \mathrm{~m}$ de arame, cobertas de arame farpado e uma faixa de asfalto correndo no meio, patrulhada pela Guarda Civil Espanhola, tudo isso monitorado por 106 câmeras de vídeo, vigilância infravermelha, um cabo microfônico e helicópteros. Em Melilla, um homem que trabalhou na cerca me contou que chegava ao trabalho pela manhã para encontrar sua escada coberta de sangue, onde migrantes tinham tentado usá-la para escalar para a cidade e se tornaram vítimas do arame farpado. (THE GUARDIAN, 2010, on-line, tradução nossa)
\end{abstract}

Melilla, por exemplo, é um dos casos que envolvem a dimensão externa da política migratória da UE, por meio da atuação da FRONTEX (JO, 2004) e da cooperação bilateral com o Marrocos (COMISSÃO, 2011), restringindo as migrações irregulares e o tráfico de imigrantes por meio da parceria e com auxílio das tecnologias que são desenvolvidas para impedir e expulsar o indesejado imigrante do Sul Global. A mensagem é esta: "não tente vir

proteção internacional é tido na lei como um nacional de um país terceiro - e, sendo irregular, é tido da mesma forma;

${ }^{25}$ Como herança da colonização, a Espanha possui duas fronteiras terrestres com a África, ambas ilhadas por territórios marroquinas e voltadas para o Mar Mediterâneo: Melilla e Celta. 
aqui, fique pobre, e se você nos desafiar, vai ser machucado" (THE GUARDIAN, 2010, tradução nossa).

Enfim, a análise geral do emaranhado político-jurídico da UE permite visualizar como o imigrante é estigmatizado e hierarquizado e, sobretudo, pode-se entender a ambivalência do status de cidadania conforme cartografias confusas. Entretanto, a avaliação dessa estratificação está incompleta, uma vez que carece de um exame aprofundado da legislação em cada Estado-membro. Trata-se aqui apenas das hierarquias de direitos em âmbito supranacional, ou seja, somente daquilo que os EM confiaram, ou cederam em parcelas de soberania, às instituições supranacionais para lidar com as questões de cidadania comum, controle de fronteiras, livre mercado e migrações.

Ainda assim, mesmo esse pequeno recorte apresentado permite perceber a hierarquização étnico/racial do ser. O projeto de integração da União Europeia, por isso, não se mostra como a melhor solução para os problemas de integração do Estado Nacional europeu. Isso ocorre porque como Hansen (2009) argumentou, não há nada que garanta uma benevolência automática dos EMs, bem como dos agentes supranacionais - em especial quanto às migrações. Não há nada que garanta a desvinculação do imaginário de procedências e precedências comuns da identidade nacional, mantendo apenas o "patriotismo constitucional" (HABERMAS, 2002, p. 135), ainda mais quando os elementos com os quais se tenta construir a identidade comum mimetizam os contornos das identidades nacionais.

Independente em qual modelo, Nacional ou Supranacional, o problema das migrações demonstra que a colonialidade - do poder, do saber e do ser - permanece como lógica operante, mantendo e reiterando as relações do sistema-mundo moderno/colonial por meio do Direito da UE. Como afirmou Grosfoguel (2009, p. 402), "não se trata de negar a importância das intervenções políticas ao nível do Estado-nação", e nesse caso ao nível supranacional. Mas, uma vez que o sistema colonial/moderno é uma sobreposição de diferentes hierarquias heterogêneas, esses campos estatais de atuação ignoram as ligações entre níveis locais e globais (abaixo e acima do Estado) e, portanto são um "espaço limitado para transformações políticas e sociais radicais" (GROSFOGUEL, 2009, p. 402).

Essas diferenças e hierarquias não podem ser superadas pelo mero exercício da supranacionalidade. A solução, por outro lado, está em reconceituar e superar a Modernidade eurocentrada e as faces da colonialidade, para promover, de fato, uma "transformação nas estruturas de poder globais" (GROSFOGUEL, 2009, p. 408). Para tal, a UE deveria acatar as propostas da "transmodernidade" (DUSSEL, 2000) e do "pensamento crítico de fronteira" 
(MIGNOLO, 2000) - a inserção das epistemologias subalternas, outras formas de se pensar a Modernidade, sem contudo negar suas contribuições emancipatórias. É necessário inserir a visão do "lado de lá", visibilizar seus saberes e aceitar outras concepções de emancipação que reconheçam de fato a alteridade e, desse modo, aceitem também humanidade do colonizado.

Assim, para superar a hierarquização do ser (racializado), a diferença que subalterniza não-europeus em favor dos europeus que são mimetizadas nas políticas migratórias e que contradizem o espírito da política de cidadania da UE, é necessário abrir o campo de visão para implementar uma nova racionalidade emancipatória. Para tal, “é essencial transformar os sistemas de dominação e de exploração da atual matriz de poder colonial do sistema-mundo patriarcal/capitalista/colonial/moderno" (GROSFOGUEL, 2009, p. 409).

\section{Considerações finais}

Em um duplo movimento histórico, o europeu marginalizou culturas, histórias e corpos. Constituiu-se o Estado-Nação paralelo à colonização, que tratou de hierarquizar e dominar a partir da ideia de identidades racializadas. A raça, antes como uma categoria taxonômica da biologia, passou a ser instrumento de classificação social a nível global. Neste sistema-mundo colonial/moderno, diversas hierarquias se sobrepujaram de forma que fatores políticos, econômicos, culturais e sociais são relevantes para dar mais direitos a uns e negá-los a outros, estratificando a sociedade mundial por meio de linhas abissais. Essas linhas, por sua vez, avançam cada vez mais para dentro dos Estados-Nação, mesmo na Europa, e assim o que antes eram linhas materiais que dividiam o colonizador do colonizado tornam-se cada vez mais linhas subjetivas.

O ser migrante do Sul Global, nesse contexto, arrisca-se para cruzar a linha da fronteira europeia, regular ou irregularmente, com o intuito de se livrar das exclusões delimitadas por fronteiras geopolíticas. No entanto, o Estado-Nação europeu traça novas fronteiras materiais ou imaginárias, que mantém a pessoa migrante em uma constante suspeita de sua humanidade em virtude de sua etnia e/ou raça. O pecado original da migração somente tende a ser parcialmente tolerado na medida em que há sua integração (ou apropriação) na sociedade, que corresponde a uma assimilação aos valores da sociedade "de acolhida". Por causa de sub-níveis de integração e diferentes status de cidadania/migração, é possível identificar na União Europeia uma classificação social, com europeus nacionais o topo da pirâmide e imigrantes irregulares em sua base. 
A proposta de integração regional europeia, como uma alternativa às contradições do Estado-Nação europeu que se propõe a concretizar a paz fundada no respeito à diversidade e aos Direitos Humanos reproduz a colonialidade e as hierarquizações, na medida em que perpetuam os elementos de identificação e exclusão em suas políticas e normas.

Desse modo, as políticas culturais que evocam o patrimônio, a história e os valores comuns dos europeus e fomentam e forjam a existência de identidade comum colidem com as políticas migratórias. Estas políticas - de controle de fronteiras, refúgio, migrações econômicas, integração de migrantes, controle de migrantes irregulares e acordos com países terceiros - uma vez que cada vez mais supranacionalizadas, não convergem para concepções menos restritivas e que levam em conta o direito de migrar. A supranacionalização das políticas migratórias operacionalizou os controles e as violências.

Isso não ocorre somente por que o modelo supranacional, que pretendia transcender o Estado-Nação, reitera as simbologias deste último - como bandeira, hino, moeda, etc. Mas, por porque reforçam a colonialidade do poder, do saber e do ser.

Desse modo, este estudo além de atestar não-transcendência da identidade nacional, demonstrou que a sociedade europeia está estratificada por meio de uma hierarquia migratória que concede mais direitos a determinadas categorias de cidadãos classificados a partir reprodução da colonialidade em escala supranacional. Ou seja, diferentes níveis de direitos regulados em escala supranacionais estão ancorados na racionalidade racial moderna.

\section{Referências bibliográficas}

ADONNINO, P. A People's Europe: Reports from the Ad Hoc Committee', Bulletin of the European Communities Supplement 7/85. Luxembourg: Office of Official Publications of the European Community, 1985.

BORG, Stefan. Euro-crafting at border zones. In: European Integration and the Problem of the State. Reino Unido: Palgrave Macmillan, 2015. pp. 117-137.

BRAGATO, Fernanda F. Discursos desumanizantes e violação seletiva de Direitos Humanos sob a lógica da colonialidade. Quaestio Iuris, v. 9, n. 4, p 1806-1823, 2016.

CASTRO-GÓMEZ, Santiago. Decolonizar La Universidad: La hybris del punto cero y el diálogo de saberes. In: CASTRO-GÓMEZ, S.; GROSFOGUEL, R.. El giro decolonial. Reflexiones para una diversidad epistémica más allá del capitalismo global. Bogotá: Siglo del Hombre Editores; Universidad Central, Instituto de Estudios Sociales Contemporáneos y Pontificia Universidad Javeriana, Instituto Pensar, 2007, p. 79-92. 
COMISSÃO EUROPEIA (COMISSÃO). Abordagem global para a migração $e$ a mobilidade. COM(2011) 743 final. Comunicação da Comissão ao Parlamento Europeu, ao Conselho, ao Comité Económico e Social Europeu e ao Comité das Regiões. Bruxelas, novembro 2011.

Comunicação da Comissão ao Parlamento Europeu, ao Conselho, ao Comité Económico e Social Europeu e ao Comité das Regiões, de 10 de Maio de 2007, sobre uma agenda europeia para a cultura num mundo globalizado (COM(2007) 242 final). Disponível em: <http://eur-lex.europa.eu/legal-content/PT/TXT/?uri=LEGISSUM:129019>. Acessado em: Março 2017.

Europa sem fronteiras: O Espaço Schengen. Brochura on-line. Disponível em: $<$ https://ec.europa.eu/home-affairs/sites/homeaffairs/files/e-

library/docs/schengen_brochure/schengen_brochure_dr3111126_pt.pdf $>$. Acessado em: Maio 2017.

Rumo a uma abordagem integrada do património cultural europeu. COM(2014) 477 final. Comunicação da Comissão ao Parlamento Europeu, ao Conselho, ao Comité Económico e Social Europeu e ao Comité das Regiões. Bruxelas, julho de 2014.

Sistema Europeu Comum de Asilo. Luxemburgo: Serviço das Publicações da União Europeia, 2014.

COMMISSION OF THE EUROPEAN COMMUNITIES (COMMISSION). A people's europe. COM (88) 331 final. Communication from the Commission to the European Parliament. Bruxelas, 7 de julho de 1988.

CONSELHO DA UNIÃO EUROPEIA (CONSELHO). Comunicação à imprensa. 2618. ${ }^{a}$ sessão do Conselho de Justiça e Assuntos Internos, Bruxelas, 19 de Novembro de 2004.

DAUVERGNE, Catherine. The close of the post-colonial. In: DAUVERGNE, Catherine. The New Pgolitics of Immigration and the End of Settler Societies. New York: University of British Colombia, Cambrige University Press, 2016, p. 150-173.

DUSSEL, Enrique. Europa, Modernidad y eurocentrismo. In: LANDER, Edgardo. La colonialidad del saber: eurocentrismo y ciencias sociales. Perspectivas latinoamericanas. Colección Sur Sur, CLACSO, Ciudad Autónoma de Buenos Aires, Argentina, 2000, p. 59-78.

FANON, Frantz. Pele negra, máscaras brancas. Bahia: Editora Edufba, 2008

GROSFOGUEL, Ramón. Para descolonizar os estudos de economia política e os estudos póscoloniais: transmodernidade, pensamento de fronteira e colonialidade global. In: SANTOS, Boaventura S; MENESES, Maria P. Epistemologias do Sul. Coimbra: Edições Almedina. 2009, p. 383-418.

HAAS, Ernst B. International integration: the European and the universal process. International organization, vol. 15, n.3, 1961, 366-392. 
HABERMAS, Jürgen. A Inclusão do Outro. Estudos de Teoria Política. São Paulo: Loyola, 2002.

HAMPSHIRE, James. European migration governance since the Lisbon treaty: introduction to the special issue. Routledge: Journal of Ethnic and Migration Studies, vol. 42, n. 4, pp. 537-553, 2016.

HANSEN, Peo. Post-national Europe - without cosmopolitan guarantees. Race \& Class, v. 50, n. 4, p 20-37, 2009.

JORNAL OFICIAL DA UNIÃO EUROPEIA (JO). DIRECTIVA 2011/95/UE DO PARLAMENTO EUROPEU E DO CONSELHO de 13 de Dezembro de 2011 que estabelece normas relativas às condições a preencher pelos nacionais de países terceiros ou por apátridas para poderem beneficiar de protecção internacional, a um estatuto uniforme para refugiados ou pessoas elegíveis para protecção subsidiária e ao conteúdo da protecção concedida (reformulação).

DIRECTIVA 2000/43/CE DO CONSELHO de 29 de Junho de 2000 que aplica o princípio da igualdade de tratamento entre as pessoas, sem distinção de origem racial ou étnica.

DIRECTIVA 2000/78/CE DO CONSELHO de 27 de Novembro de 2000 que estabelece um quadro geral de igualdade de tratamento no emprego e na actividade profissional.

DIRECTIVA 2003/109/CE DO CONSELHO de 25 de Novembro de 2003 relativa ao estatuto dos nacionais de países terceiros residentes de longa duração.

DIRECTIVA 2003/86/CE DO CONSELHO de 22 de Setembro de 2003 relativa ao direito ao reagrupamento familiar.

DIRECTIVA 2008/115/CE DO PARLAMENTO EUROPEU E DO CONSELHO de 16 de Dezembro de 2008 relativa a normas e procedimentos comuns nos Estados-Membros para o regresso de nacionais de países terceiros em situação irregular.

DIRECTIVA 2009/50/CE DO CONSELHO de 25 de Maio de 2009 relativa às condições de entrada e de residência de nacionais de países terceiros para efeitos de emprego altamente qualificado.

DIRECTIVA 2011/98/UE DO PARLAMENTO EUROPEU E DO CONSELHO de 13 de Dezembro de 2011 relativa a um procedimento de pedido único de concessão de uma autorização única para os nacionais de países terceiros residirem e trabalharem no território de um Estado-Membro e a um conjunto comum de direitos para os trabalhadores de países terceiros que residem legalmente num Estado-Membro.

DIRECTIVA 2013/32/UE DO PARLAMENTO EUROPEU E DO CONSELHO, de 26 de junho de 2013, relativa a procedimentos comuns de concessão e retirada do estatuto de proteção internacional (reformulação) 
DIRECTIVA 2013/33/UE DO PARLAMENTO EUROPEU E DO CONSELHO de 26 de junho de 2013 que estabelece normas em matéria de acolhimento dos requerentes de proteção internacional (reformulação).

. DIRECTIVA 2014/36/UE DO PARLAMENTO EUROPEU E DO CONSELHO de 26 de fevereiro de 2014 relativa às condições de entrada e de permanência de nacionais de países terceiros para efeitos de trabalho sazonal.

ACORDO L 134/3, de 7 de maio de 2014, entre a União Europeia e a República da Turquia sobre a readmissão de pessoas que residem sem autorização

DIRECTIVA 2016/801/UE DO PARLAMENTO EUROPEU E DO CONSELHO de 11 de maio de 2016 relativa às condições de entrada e de residência de nacionais de países terceiros para efeitos de investigação, de estudos, de formação, de voluntariado, de programas de intercâmbio de estudantes, de projetos educativos e de colocação au pair (reformulação).

DIRECTIVA 2016/399/UE DO PARLAMENTO EUROPEU E DO CONSELHO de 9 de março de 2016, que estabelece o código da União relativo ao regime de passagem de pessoas nas fronteiras (Código das Fronteiras Schengen)

RECOMENDAÇÃO (UE) 2015/914 DA COMISSÃO de 8 de junho de 2015 relativa a um regime de reinstalação europeu.

REGULAMENTO (CE) n. ${ }^{\circ} 2725 / 2000$ do Conselho, de 11 de dezembro de 2000, relativa à criação do Sistema «Eurodac» de comparação de impressões digitais para efeitos da aplicação da Convenção de Dublim.

REGULAMENTO (CE) N.o 2007/2004 DO CONSELHO de 26 de Outubro de 2004 que cria uma Agência Europeia de Gestão da Cooperação Operacional nas Fronteiras Externas dos Estados-Membros da União Europeia (FRONTEX). 326/49).

Tratado sobre o funcionamento da União Europeia (Versão consolidada). (2012/C Carta dos Direitos Fundamentais da União Europeia. (2000/C 364/01).

CONVENÇÃO sobre a determinação do Estado responsável pela análise de um $\overline{\text { pedido }}$ de asilo apresentado num Estado-membro das Comunidades Europeias. (1997/C 254/01).

LANDER, Edgardo. Ciencias sociales: saberes coloniales y eurocéntrico. In: colonialidad del saber: eurocentrismo y ciencias sociales. Perspectivas latinoamericanas. Colección Sur Sur, CLACSO, Ciudad AutÛnoma de Buenos Aires, Argentina, 2000, p. 4-23.

LISBOA, Armando de Melo. De América a Abya Yala - semiótica da descolonização. Revista Educação Pública, Cuiabá, v. 23, n. 53/2, p. 501-531, maio/ago. 2014.

MALDONADO-TORRES, Nelson. Sobre la colonialidad del ser: contribuciones al desarrollo de un concepto. In: CASTRO-GÓMEZ, S.; GROSFOGUEL, R. El giro decolonial. Reflexiones para una diversidad epistémica más allá del capitalismo global. Bogotá: Siglo del 
Hombre Editores; Universidad Central, Instituto de Estudios Sociales Contemporáneos y Pontificia Universidad Javeriana, Instituto Pensar, 2007, p. 127-167.

MARTINIELLO, Marco. The new migratory Europe: Towards a proactive immigration policy? In: PARSONS, A. Craig; SMEEDING, Timothy M. Immigration and the transformation of Europe. Cambridge: Cambridge Press, 2009. p. 419-441.

Organização das Nações Unidas (ONU). Assembléia Geral. Declaração Universal dos Direitos do Homem. 1948.

PERSAUD, Randolph. Situating Race in International Relations. In: Chowdry, G. and Nair, S. eds. Power, Postcolonialism and International Relations. Londres: Routledge, 2002, p. 5681.

POLAT, Necati. European integration as colonial discourse. Review of International Studies, v. 37, n. 3, p. 1255-1272, 01 jul. 2011.

POLITICO. Hungary hardens immigration line: Prime Minister Orbán's government expects protests from Brussels but has vowed to press ahead. Fevereiro de 2017. Disponível em: $<$ http://www.politico.eu/article/hungarys-new-hardline-immigration-scheme-viktor-orbanrefugees-migration-crisis-europe/>. Acessado em: Maio 2017.

QUIJANO, Aníbal. Colonialidade do poder, eurocentrismo e América Latina. In: LANDER, Edgardo (org.) A colonialidade do saber: eurocentrismo e ciências sociais. Perspectivas latino-americanas. Buenos aires: Colección Sur Sur, CLACSO, set. 2005, p 107-130

Colonialidad del poder e clasificación social. El giro decolonial. Reflexiones para una diversidad epistémica más allá del capitalismo global. Bogotá: Siglo del Hombre Editores; Universidad Central, Instituto de Estudios Sociales Contemporáneos y Pontificia Universidad Javeriana, Instituto Pensar, 2007, p. 93-126.

SANTOS, Boaventura S. Para além do pensamento abissal: das linhas globais a uma ecologia de saberes. In: SANTOS, Boaventura S; MENESES, Maria P. Epistemologias do Sul. Coimbra: Edições Almedina. 2009, p. 23-72.

SAYAD, Abdelmalek. Immigration and 'state thought'. In: MARTINIELLO, Marco; RATH, Jan. Selected studies in International Migration and Immigrant incorporation. Admesterdão: IMISCOE, 2004, p. 165-179.

SEBASTIANI, De Luca. La colonialidad del poder y del saber en las políticas públicas de la Unión Europea: Reflexiones a partir de una investigación sobre "inmigración" e “integración”. Revista de Antropología Experimental, n. 15, 2015, p. 535-522.

SILVA, Karine de Souza; COSTA, Rogério Santos da. Organizações Internacionais de Integração Regional: União Europeia, MERCOSUL e UNASUL.

Florianópolis: Ed. UFSC/Funjab, 2013.

SHORE, Chris. Transcending the Nation-State?: the European Commission and the (re)discovery of Europe. Journal Of Historical Sociology, v. 9, n. 4, p. 473-496, dec. 1996. 
THE GUARDIAN. Melilla: Europe's dirty secret. 17 abril 2010. Disponível em: <https://www.theguardian.com/world/2010/apr/17/melilla-migrants-eu-spain-morocco>. Acessado em: Junho 2017.

TINDEMANS, Leo. (1976) European Union. Report by Mr. Leo Tindemans, Prime Minister of Belgium, to the European Council. Bulletin of the European Communities, Supplement 1/76. Disponível em: < http://aei.pitt.edu/942/1/political_tindemans_report.pdf $>$. Acessado em: Ago. 2018

WALLERSTEIN, Immanuel. Historical origins of world-system analysis. In: World-system analysis. An introduction. Durham e Londres: Duke University press, 2006, p.1-22.

\title{
Dois Pesos e Duas Medidas: a projeção da colonialidade nas políticas de migração e de cidadania da União Europeia
}

\begin{abstract}
Resumo
O presente artigo objetiva evidenciar que as políticas de migrações e de cidadania da União Europeia reproduzem a colonialidade em escala supranacional porque perpetuam as hierarquizações coloniais entre europeus e não-europeus fundadas na ideia de raça. Levanta-se a hipótese segundo a qual o processo de supranacionalização das migrações e da identidade comum na UE reitera os elementos da colonialidade devido à concepção fortemente racial que contemplam, que separa os ex-colonizadores dos ex-colonizados por meio de linhas abissais. Desconstrói-se a tese de que a integração regional europeia supera os elementos de classificação social presentes no Estado nacional europeu, em especial quanto às migrações não-europeias. Assim, a primeira parte do presente trabalho confronta, a partir da literatura, a proposta de integração da União Europeia com as estruturas coloniais de poder, de saber e do ser quanto à raça e etnia. Em seguida, a segunda seção apresenta as políticas de migrações e de cidadania da União Europeia. Por fim, a última parte demonstra, a partir do resumo dos direitos e das restrições expostas, como a colonialidade do ser é reproduzida em escala supranacional, a partir da análise de cada classificação social entre europeus e não-europeus.
\end{abstract}

Palavras-chave: migrações; cidadania; colonialidade; União Europeia

\section{Two Weights and Two Measures: the projection of coloniality in migration and citizenship Policies of the European Union}

\begin{abstract}
The present article aims to show that the European Union's migration and citizenship policies reproduce coloniality on a supranational scale because they perpetuate the colonial hierarchies between Europeans and nonEuropeans based on the idea of race. The hypothesis arises that the process of supranationalisation of migration and of common identity in the EU reiterates the elements of coloniality due to the strongly racial conception they contemplate, separating the ex-colonizers from the ex-colonized by abyssal lines. The argument that European regional integration exceeds the elements of social classification present in the European national state, especially with regard to non-European migrations, is deconstructed. Thus, the first part of the present paper confronts, from the literature, the proposal of integration of the European Union with the colonial structures of power, of knowledge and of being about race and ethnicity. Next, the second section presents the migration and citizenship policies of the European Union. Finally, the last part demonstrates, from the summary of rights and restrictions exposed, how the coloniality of being is reproduced on a supranational scale, from the analysis of each social classification between Europeans and non-Europeans.
\end{abstract}

Keywords: migration; citizenship; coloniality; European Union 


\section{Dos Pesos y Dos Medidas: la proyección de la colonialidad en las políticas de migración y de ciudadanía de la Unión Europea}

\section{Resumen}

El presente artículo tiene por objeto evidenciar que las políticas de migración y de ciudadanía de la Unión Europea reproducen la colonialidad a escala supranacional porque perpetúan las jerarquías coloniales entre europeos y no europeos fundadas en la idea de raza. Se levanta la hipótesis según la cual el proceso de supranacionalización de las migraciones y de la identidad común en la UE reitera los elementos de la colonialidad debido a la concepción fuertemente racial que contemplan, que separa a los ex colonizadores de los ex colonizados por medio de líneas abisales. Se deconstruye la tesis de que la integración regional europea supera los elementos de clasificación social presentes en el Estado nacional europeo, en particular en lo que se refiere a las migraciones no europeas. Así, la primera parte del presente trabajo confronta, a partir de la literatura, la propuesta de integración de la Unión Europea con las estructuras coloniales de poder, de saber y del ser en cuanto a raza y etnia. A continuación, la segunda sección presenta las políticas de migración y de ciudadanía de la Unión Europea. La parte final demuestra, a partir del resumen de los derechos y de las restricciones expuestas, como la colonialidad del ser se reproduce a escala supranacional, a partir del análisis de cada clasificación social entre europeos y no europeos.

Palabras clave: migraciones; ciudadanía; colonialidad; Unión Europea 